\title{
Soil oribatid mite in four typical vegetation communities of Misiones forest in the Iguazú area, Argentina
}

\author{
Pablo Antonio Martínez ${ }^{(1)}$, Natalia Andrea Fredes ${ }^{(1,2)}$, Lia Fernanda Montti ${ }^{(2,3,4)}$ \\ and Sergio Alejandro Casertano ${ }^{(4,5)}$
}

\begin{abstract}
(1) Universidad Nacional de Mar del Plata, Facultad de Ciencias Exactas y Naturales, Departamento de Biología, Funes 3350,7600 Mar del Plata, Argentina ${ }^{(2)}$ Consejo Nacional de Investigaciones científicas y técnicas, ${ }^{(3)}$ Universidad de Buenos Aires, Facultad de Ciencias, Exactas y Naturales, Departamento de Ecología, Genética y Evolución, Laboratorio de Ecología Funcional (LEF). Ciudad Universitaria, Pabellón II, 2 piso, Ciudad de Buenos Aires (C1428EHA), Argentina ${ }^{(4)}$ Centro de Investigaciones del Bosque Atlántico (CelBA), Puerto Iguazú, Misiones, Argentina ${ }^{(5)}$ ONG Conservación Argentina, Salta 117, Puerto Iguazú, Misiones, Argentina. E-mail: pamartin@mdp.edu.ar
\end{abstract}

Abstract - The objective of this work was to assess the soil oribatid mite communities in four sites of the Upper Paraná Bosque Atlántico, in the Iguazú National Park, Argentina and in surrounding areas: bamboo forest, palm forest and two mixed forests. A comparison between each pair of sites, based on the presence-absence of oribatid species, was performed using Jaccard's index. This is the first systematic sampling of oribatid mites in this area. A total of 56 genera and 96 oribatid species were found, 25 and 49 of them, respectively, are new citation for Argentina. The highest similarity was found between mixed forests. Almost $68 \%$ and $34 \%$ of the genera were cited for similar biotopes in Brazil and Paraguay, respectively.

Index terms: bamboo, biogeography, bioprospection mixed forest, palm, soil mites.

\section{Ácaros oribatídeos do solo em quatro comunidades vegetais da floresta de Misiones, na região de Iguazú, Argentina}

Resumo - O objetivo deste trabalho foi avaliar as comunidades de oribatídeos em quatro sítios da Mata Atlântica do Alto Paraná, na área do Parque Nacional Iguazú, Argentina, e em áreas adjacentes: floresta de bambu, floresta de palmito e duas florestas mistas. Foi feita uma comparação de cada par de sítios, com base na presença/ausência de oribatídeos, por meio do índice de Jaccard. Esta é a primeira amostragem sistemática dos oribatídeos dessa região. Cinquenta e seis gêneros e 96 espécies de oribatídeos foram encontrados, dos quais 25 e 49, respectivamente, são citados pela primeira vez para a Argentina. A maior similiraridade foi encontrada entre as duas florestas mistas. Quase $68 \%$ e $34 \%$ dos gêneros já foram coletados em biótopos similares no Brasil e no Paraguai, respectivamente.

Termos para indexação: bambu, biogeografia, bioprospecção, floresta mista, palmito, ácaros do solo.

\section{Introduction}

The AtlanticForest ecoregion is the most threatened tropical ecosystem on the planet (Galindo-Leal \& Gusmão Câmara, 2003). However, the remnants still hold high biological diversity and endemism (Myers, 2000) that are scarcely legally under protected areas (Tabarelli et al., 2005). The Atlantic Region is extremely heterogeneous in structure and species composition as a result of different climatic and edafic conditions across its distributional range. Accordingly, major different forest ecosystem types have been recognized: the Atlantic Rainforest and the inland semideciduous Atlantic Forest (Oliveira Filho $\&$ Fontes, 2000). The semideciduous Atlantic Forest occupies areas of southern Brazil, east of Paraguay and north of Argentina. This biome suffered a hard exploitation during the last century (Holz \& Placci, 2003; Campanello et al., 2009), with less than $10 \%$ of its original surface being preserved at present. In the Argentinian portion, the best preserved continuous remnants occur, representing $44 \%$ of the original covering in this country (Campanello et al., 2007), whose largest preserved area is located in the Iguazú National Park (65,000 ha) and surrounding 
areas in the north of Misiones province (DiBitetti et al., 2003).

The complexity and diversity of oribatid mites in tropical areas and the lack of specialists in the region make oribatids a poorly known group in these areas. Despite the Argentina holding of the best preserved areas of the Semidecidual Atlantic Forest and the importance of Oribatid communities as ecological indicators, no bio-prospecting for mites have been performed there.

The objective of this work was to assess the soil oribatid mites communities composition in four vegetation sites in this region, the relations between mite community composition and vegetation cover, and also to compare the mite communities among sites, and among areas of Brazil and Paraguay belonging to the same biogeographical region.

\section{Materials and Methods}

The climate in the Atlantic Forest of Argentina is subtropical with monthly average temperature variations of about $10^{\circ} \mathrm{C}$ between the warmest and the coldest months, with certain probability of freezing temperatures from middle June to middle September. Annual precipitation ranges from 1,900 to 2,100 mm (Ligier, 2000). Rainfall is evenly distributed along the year, but short dry spells can occur. The topography of this region in northeastern Argentina is undulated, as a result of a dense network of rivers eroding a basalt formation (Tujchneider et al., 2007). The soils are derived from basaltic rocks with a high concentration of $\mathrm{Fe}, \mathrm{Al}$ and $\mathrm{Si}$, and are well drained (Ligier, 2000).

Two sites were sampled inside the Iguazú National Park: palm forest or "Palmital" (PA) and bamboo forest or "Bambusal" (BA), separated $20 \mathrm{~km}$ one from mother (Figure 1). The first is a forest dominated by

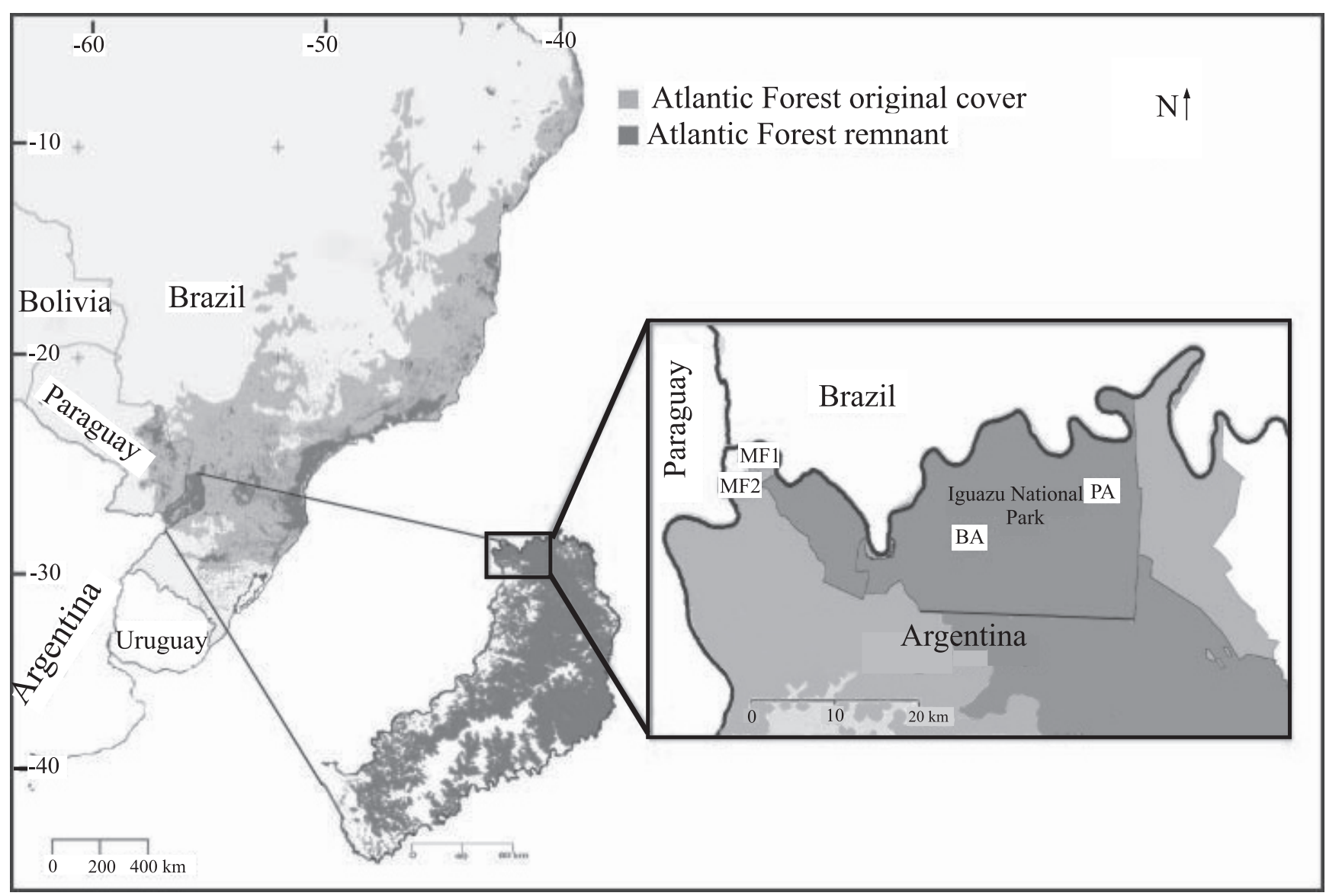

Figure 1. Map of the sample sites. MF1 and MF2, mixed forests 1 and 2, respectively; BA, bamboo forest, PA, palm forest. Map modified from Di Bitetti et al. (2003). 
heart-of-palm trees (Euterpe edulis), in a density near 728 individuals per hectare, and whit the sporadic presence of other trees like rosewood (Aspidosperma polyneuron), Lauraceas (specially Nectandra megapotamica), and Chrysophylum gonocarpum (Srur et al., 2007). This palm constitutes a dense cover between 4 and $18 \mathrm{~m}$ height. The understorey of palm forest is shadowed, wet and open with fern, shrubs and tree saplings (Gatti, 2005). Bamboo forest includes big forest gaps dominated by woody bamboos (Chusquea ramosissima and Merostachys spp.) that form impenetrable thickets in the understorey. Big gaps and open canopy areas with isolated trees and scarce diversity constitute the forests. There are sites associated to natural or anthropogenic disturbs. The organic soils were deep with high content of bamboo leaf.

Other two sample sites were located outside the National Park, and were constituted by native and exotic tree species (mixed forests 1 and $2-$ MF1 and MF2, respectively) (Figure 1). They were located $24 \mathrm{~km}$ away from the closest site in the National Park, and were separated one from another by $3 \mathrm{~km}$. These forests presented a mixed tall and open canopy. Some of the dominant canopy trees were: Balfourodendron riedelianum (Engl.) Engl., Nectandra megapotamica (Spreng.) Mez, Bastardiopsis densiflora (Hook. \& Arn.) Hassler and Lonchocarpus leucanthus Burkart. Common subdominant tree species are Sorocea bonplandii (Baill.) W.C. Burger, Lanj. \& Boer Actinostemon concolor (Spreng.) Muell. Arg., Trichilia catigua A. Juss. and Trichilia elegans A. Juss. The understorey is dense, wet, shadowed, and presents some Piperaceae, Bambusaceae, lianas and different native and exotic herbs.

Ten samples whit $8-\mathrm{cm}$ diameter and 5 -cm deep were taken from each site in November 2006. They were distributed along a transect, with a distance of $5 \mathrm{~m}$ between samples. Microarthropods were extracted by Berlese funnels and preserved in ethanol $70 \%$. Oribatid mites were identified to species level using identification keys (Balogh \& Balogh, 1988, 1990, 1992a, 1992b). Specific taxonomical bibliography was used, in order to check some determinations. The classification system adopted was based on that of Subías (2004). The term "cf." (in some of the listed species) refers to an uncertainty in the identification. A comparison among sites, based on presence-absence of oribatid species, was made using Jaccard's similarity index, recommended to work with qualitative data (Moreno, 2001). Species composition was compared with those found in nearly areas of Brazil and Paraguay, based on bibliography (Pérez-Iñigo \& Baggio, 1980, 1985, 1986, 1988, 1989, 1991, 1993, 1994; Mahunka, 1984; Oliveira et al., 2005;).

\section{Results and Discussion}

No systematic studies on oribatid fauna were made in the Iguazú area before this study. Only eight phthiracarid species were cited by Mahunka (2004) from Iguazú National Park and Iguazú Falls. In the present work, a total of 56 genera and 96 species of oribatid mites were found (Table 1). Twenty-five genera and 49 species constitute new citations for Argentina. The number of species was similar among sites: $\mathrm{PA}=35, \mathrm{BA}=41, \mathrm{MF} 1=45, \mathrm{MF} 2=51$. Many species were recorded in only one site in this study: 6 species in MF1, 14 in MF2, 12 in BA and 15 in PA. Some genera were represented by different species in different sites (e.g. Scheloribates, Lamellobates). Some phylogenetically associated species groups showed a clear distribution, and were present in bamboo forest and in palm forest, but not in the mixed forests, or vice-versa. All of Plateremaeoids (species 22 to 26, numbered in Table 1) were present only in BA and PA, whereas all suctobelbids (species 59 to 64) were present only in mixed forests. Some haplozetid-protoribatid species (two Protoribates, two Indoribates and one Lauritzenia (species 83 to 87), but no other haplozetid species, as Rostrozetes or Peloribates, showed the later distribution too.

The highest similarity value among sites (Jaccard's index) was found for MF1 and MF2 (Table 2). The sampled area in this study shared almost $68 \%$ of the genera collected with similar biotopes of south of Brazil (Pérez-Iñigo \& Baggio, 1980, 1985, 1986, 1988, 1989, 1991, 1993, 1994; Oliveira et al., 2005), and 34\% with those of Paraguay (Mahunka, 1984). As expected, the number of shared species was higher than the number of shared genera in both cases (Table 3). However, these results are not definitive, because a stronger sampling effort in our work certainly could result in a higher number of collected species, whereas the data taken from bibliography are not exhaustive. Oliveira et al. (2005) reported that the species mentioned in their paper represented about $20 \%$ of the species 
Table 1. Oribatid mite species collected in mixed forests (MF1, MF2), in forest dominated by bamboo (BA), and in forest dominated by palm trees (PA).

\begin{tabular}{|c|c|c|c|c|c|}
\hline $\mathrm{N}^{\mathrm{o}}$ & Species $^{(1)}$ & MF1 & MF2 & BA & PA \\
\hline 1 & Eohypochthonius becki ${ }^{(1)}$ & $\mathrm{x}$ & $\bar{x}$ & $\mathrm{x}$ & - \\
\hline 2 & Malacoangelia remigera ${ }^{(2)}$ & - & $\mathrm{x}$ & - & - \\
\hline 3 & Epilohmannia lenkoi $?^{(1)}$ & $\mathrm{x}$ & - & - & $\mathrm{x}$ \\
\hline 4 & Epilohmannia pallida americana & $\mathrm{x}$ & $\mathrm{x}$ & - & $\mathrm{x}$ \\
\hline 5 & Torpacarus omittens paraguayensis ${ }^{(1)}$ & $\mathrm{x}$ & $\mathrm{x}$ & - & - \\
\hline 6 & Rhysotritia peruensis & $\mathrm{x}$ & $\mathrm{x}$ & $\mathrm{x}$ & $\mathrm{x}$ \\
\hline 7 & Rhysotritia cf. monodactyla & - & - & - & $\mathrm{x}$ \\
\hline 8 & Atropacarus (Hoplophorella) cucullatus ${ }^{(2)}$ & $\mathrm{x}$ & $\mathrm{x}$ & $\mathrm{x}$ & $\mathrm{x}$ \\
\hline 9 & Atropacarus (Hoplophorella) vitrinus $^{(2)}$ & $\mathrm{x}$ & - & - & - \\
\hline 10 & Atropacarus (Hoplophorella) cochlearis? ${ }^{(2)}$ & - & - & - & $\mathrm{x}$ \\
\hline 11 & Notophthiracarus (Protophthiracarus) grandjeani ${ }^{(1)}$ & - & - & $\mathrm{x}$ & - \\
\hline 12 & Notophthiracarus (Protophthiracarus) sp. & - & - & - & $\mathrm{x}$ \\
\hline 13 & Steganacarus? sp. & - & - & - & $\mathrm{x}$ \\
\hline 14 & Malaconothrus cf. sylvaticus & $\mathrm{x}$ & - & $\mathrm{x}$ & $\mathrm{x}$ \\
\hline 15 & Malaconothrus cf. hauseri & - & $\mathrm{x}$ & - & - \\
\hline 16 & Nothrus macedi ${ }^{(1)}$ & $\mathrm{x}$ & - & $\mathrm{x}$ & - \\
\hline 17 & Masthermannia cf. mamillaris ${ }^{(2)}$ & $\mathrm{x}$ & - & - & - \\
\hline 18 & Baloghacarus australis $^{(2)}$ & $\mathrm{x}$ & $\mathrm{x}$ & $\mathrm{x}$ & $\mathrm{x}$ \\
\hline 19 & Hermannobates n. sp. ${ }^{(2)}$ & - & - & $\mathrm{x}$ & - \\
\hline 20 & Hermannobates flagelliseta ${ }^{(2)}$ & - & - & - & $\mathrm{x}$ \\
\hline 21 & Plasmobates $\mathrm{n} . \mathrm{sp} .^{(1)}$ & $\mathrm{x}$ & $\mathrm{x}$ & $\mathrm{x}$ & $\mathrm{x}$ \\
\hline 22 & Teleioliodes n. sp. ${ }^{(2)}$ & - & - & $\mathrm{x}$ & - \\
\hline 23 & Teleioliodes zikani $^{(2)}$ & - & - & $\mathrm{x}$ & $\mathrm{x}$ \\
\hline 24 & Plateremaeus $\mathrm{cf}$ ornatissimus $^{(2)}$ & - & - & $\mathrm{x}$ & $\mathrm{x}$ \\
\hline 25 & Pheroliodes sp. & - & - & $\mathrm{x}$ & $\mathrm{x}$ \\
\hline 26 & Pheroliodes cf. intermedius & - & - & $\mathrm{x}$ & - \\
\hline 27 & Austrodamaeus elegantulus & $\mathrm{x}$ & $\mathrm{x}$ & - & $\mathrm{x}$ \\
\hline 28 & Microtegeus cf. borhidii ${ }^{(2)}$ & - & - & $\mathrm{x}$ & - \\
\hline 29 & Microtegeus cardosensis $^{(2)}$ & $\mathrm{x}$ & $\mathrm{x}$ & - & $\mathrm{x}$ \\
\hline 30 & Charassobates tuberosus ${ }^{(2)}$ & $\mathrm{x}$ & - & $\mathrm{x}$ & $\mathrm{x}$ \\
\hline 31 & Acaroceras aff. furcatus $^{(2)}$ & - & - & - & $\mathrm{x}$ \\
\hline 32 & Berlesezetes brasilozetoides & $\mathrm{x}$ & $\mathrm{x}$ & $\mathrm{x}$ & - \\
\hline 33 & Phylacozetes sp. ${ }^{(2)}$ & $\mathrm{x}$ & $\mathrm{x}$ & - & - \\
\hline 34 & Rophalozetes sp. $^{(2)}$ & - & - & - & $\mathrm{x}$ \\
\hline 35 & Cultroribula zicsii & $\mathrm{x}$ & - & $\mathrm{x}$ & - \\
\hline 36 & Ceratorchestes $\mathrm{n} . \mathrm{sp}^{(2)}$ & - & $\mathrm{x}$ & $\mathrm{x}$ & - \\
\hline 37 & Eremulus rigidisetosus $^{(1)}$ & $\mathrm{x}$ & $\mathrm{x}$ & $\mathrm{x}$ & - \\
\hline 38 & Fosseremus laciniatus & $\mathrm{x}$ & - & $\mathrm{x}$ & - \\
\hline 39 & Eremobelba zicsii $^{(1)}$ & $\mathrm{x}$ & $\mathrm{x}$ & $\mathrm{x}$ & - \\
\hline 40 & Eremobelba sp. & - & $\mathrm{x}$ & - & - \\
\hline 41 & Stauroma n. sp. ${ }^{(2)}$ & - & $\mathrm{x}$ & - & - \\
\hline 42 & Pletzenoppia?sp. & $\mathrm{x}$ & - & - & - \\
\hline 43 & Brachioppia sp. & $\mathrm{x}$ & $\mathrm{x}$ & $\mathrm{x}$ & - \\
\hline 44 & Brachioppia tropicalis $^{(1)}$ & - & - & - & $\mathrm{x}$ \\
\hline 45 & Brachioppia aff. pseudocostulata & $\mathrm{x}$ & $\mathrm{x}$ & - & - \\
\hline 46 & Microppia minus & - & $\mathrm{x}$ & - & - \\
\hline 47 & Oxyoppia (Oxyoppiella) suramericana & $\mathrm{x}$ & $\mathrm{x}$ & - & $\mathrm{x}$ \\
\hline 48 & Ramusella (Inscultoppia) merimna? & $\mathrm{x}$ & $\mathrm{x}$ & - & - \\
\hline 49 & Globoppia o Lanceoppia sp. & - & - & - & $\mathrm{x}$ \\
\hline 50 & Trapezoppia longipectinata $^{(2)}$ & - & - & - & $\mathrm{x}$ \\
\hline 51 & Corynoppia sp. ${ }^{(2)}$ & - & $\mathrm{x}$ & - & - \\
\hline 52 & Amerioppia barrancensis paraguayensis ${ }^{(1)}$ & - & - & $\mathrm{x}$ & - \\
\hline 53 & Pseudoamerioppia paraguayensis ${ }^{(2)}$ & - & $\mathrm{x}$ & $\mathrm{x}$ & - \\
\hline 54 & Striatoppia opuntiseta ${ }^{(2)}$ & - & $\mathrm{x}$ & - & - \\
\hline 55 & Teratoppia sp. & - & $\mathrm{x}$ & $\mathrm{x}$ & - \\
\hline 56 & Teratoppia sp. 2 & $\mathrm{x}$ & - & - & - \\
\hline 57 & Teratoppia $\mathrm{n} . \mathrm{sp}$. & - & $\mathrm{x}$ & - & - \\
\hline 58 & Teratoppia cf. pluripectinata & - & $\mathrm{x}$ & - & - \\
\hline 59 & Neosuctobelba transitoria ${ }^{(2)}$ & $\mathrm{x}$ & $\mathrm{x}$ & - & - \\
\hline 60 & Novosuctobelba (Coartobelba) transversalis ${ }^{(2)}$ & $\mathrm{x}$ & $\mathrm{x}$ & - & - \\
\hline 61 & Suctobelbella (Ussuribata) longiclava & $\mathrm{x}$ & - & - & - \\
\hline 62 & Suctobelbella (Flagrosuctobelba) peracuta ${ }^{(1)}$ & $\mathrm{x}$ & $\mathrm{x}$ & - & - \\
\hline 63 & Suctobelbella (Suctobelbella) ornatissima & $\mathrm{x}$ & $\mathrm{x}$ & - & - \\
\hline
\end{tabular}


Table 1. Continuation...

\begin{tabular}{|c|c|c|c|c|c|}
\hline$\overline{64}$ & Suctobelbella subcomplexa & - & $\mathrm{x}$ & - & - \\
\hline 65 & Carabodes (Austrocarabodes ?) n. sp. ${ }^{(1)}$ & $\mathrm{x}$ & $\mathrm{x}$ & $\mathrm{x}$ & $\mathrm{x}$ \\
\hline 66 & Carabodidae sp. & - & - & - & $\mathrm{x}$ \\
\hline 67 & Tectocepheus velatus & $\mathrm{x}$ & $\mathrm{x}$ & $\mathrm{x}$ & $\mathrm{x}$ \\
\hline 68 & Tectocepheus americanus? & - & - & - & $\mathrm{x}$ \\
\hline 69 & Tegeozetes $\mathrm{n} . \mathrm{sp}^{(2)}$ & - & - & - & $\mathrm{x}$ \\
\hline 70 & Scapheremaeus sp. & $\mathrm{x}$ & - & - & - \\
\hline 71 & Allozetes n. sp. & - & $\mathrm{x}$ & - & - \\
\hline 72 & Lamellobates quadricornis ${ }^{(1)}$ & - & - & $\mathrm{x}$ & $\mathrm{x}$ \\
\hline 73 & Lamellobates molecula $^{(2)}$ & $\mathrm{x}$ & $\mathrm{x}$ & - & - \\
\hline 74 & Ceratobates spatulatus $^{(2)}$ & $\mathrm{x}$ & $\mathrm{x}$ & $\mathrm{x}$ & - \\
\hline 75 & Ceratobates fornerisae ${ }^{(2)}$ & - & - & - & $\mathrm{x}$ \\
\hline 76 & Hemileius suramericanus & $\mathrm{x}$ & $\mathrm{x}$ & $\mathrm{x}$ & - \\
\hline 77 & Scheloribates praencisus sandvicensis ${ }^{(1)}$ & $\mathrm{x}$ & - & - & - \\
\hline 78 & Scheloribates praencisus acutivclava ${ }^{(1)}$ & - & $\mathrm{x}$ & $\mathrm{x}$ & $\mathrm{x}$ \\
\hline 79 & Scheloribates sp. & - & $\mathrm{x}$ & - & - \\
\hline 80 & Scheloribates pauliensis $^{(1)}$ & - & - & - & $\mathrm{x}$ \\
\hline 81 & Scheloribates cf. parvialatus & - & - & $\mathrm{x}$ & - \\
\hline 82 & Scheloribates elegans ${ }^{(1)}$ & $\mathrm{x}$ & $\mathrm{x}$ & - & - \\
\hline 83 & Protoribates (Protoribates) capucinus capucinus & $\mathrm{x}$ & $\mathrm{x}$ & - & - \\
\hline 84 & Protoribates (Triaungius) praeoccupatus & $\mathrm{x}$ & - & - & - \\
\hline 85 & Indoribates (Mancoribates?) sp. & - & $\mathrm{x}$ & - & - \\
\hline 86 & Indoribates (Haplozetes) nudus & - & $\mathrm{x}$ & - & - \\
\hline 87 & Lauritzenia longipluma & - & $\mathrm{x}$ & - & - \\
\hline 88 & Peloribates sp. & - & $\mathrm{x}$ & $\mathrm{x}$ & - \\
\hline 89 & Trachyoribates (Rostrozetes) ovulum ovulum & $\mathrm{x}$ & $\mathrm{x}$ & $\mathrm{x}$ & $\mathrm{x}$ \\
\hline 90 & Trachyoribates (Rostrozetes) heterotrichus ${ }^{(1)}$ & - & - & $\mathrm{x}$ & \\
\hline 91 & Galumna (Galumna) flabellifera & $\mathrm{x}$ & $\mathrm{x}$ & $\mathrm{x}$ & $\mathrm{x}$ \\
\hline 92 & Carinogalumna clericata & $\mathrm{x}$ & $\mathrm{x}$ & - & - \\
\hline 93 & Pergalumna decoratissima ${ }^{(1)}$ & - & - & $\mathrm{x}$ & - \\
\hline 94 & Pergalumna aff. nasica & - & - & $\mathrm{x}$ & - \\
\hline 95 & Pergalumna sp. & - & - & $\mathrm{x}$ & - \\
\hline & Allogalumna alpha ${ }^{(2)}$ & - & - & $\mathrm{x}$ & - \\
\hline \multicolumn{2}{|c|}{ Number of species } & 45 & 51 & 41 & 35 \\
\hline \multicolumn{2}{|c|}{ Porcentage of total observed species } & $46.9 \%$ & $53.1 \%$ & $42.7 \%$ & $36.5 \%$ \\
\hline
\end{tabular}

(1)The sign "?" (in some of the listed species) refers to an uncertainty in the identification, and the term "cf." indicates "to be compared with". (2)Species cited for the first time for Argentina. ${ }^{(3)}$ Species and genus cited for the first time for Argentina.

Table 2. Similarity (Jaccard's index) of oribatid communities among sample sites.

\begin{tabular}{lccc}
\hline Site & Palm forest & Mixed forest 1 & Mixed forest 2 \\
\hline Bamboo forest & 0.25 & 0.30 & 0.28 \\
Palm forest & - & 0.23 & 0.18 \\
Mixed forest 1 & - & - & 0.48 \\
\hline
\end{tabular}

Table 3. Comparison of oribatid composition among geographic areas.

\begin{tabular}{lccc}
\hline Oribatid & This study & South of Brasil $^{(1)}$ & Paraguay $^{(2)}$ \\
\hline Genera/species cited & $56 / 96$ & $97 / 167$ & $37 / 43$ \\
Genera shared & - & $38(67.8 \%)$ & $19(33.9 \%)$ \\
Species shared & - & $19(19.8 \%)$ & $6(6.25 \%)$ \\
\hline
\end{tabular}

(1)Reference: Pérez-Iñigo \& Baggio (1980, 1985, 1986, 1988, 1989, 1991, 1993, 1994); Oliveira et al. (2005). ${ }^{(2)}$ Reference: Mahunka (1984).

actually collected by them; and that the great number of morphological species found in their study indicates the great diversity of Oribatida in the areas where the study was conducted. The main objective of the cited works of Mahunka and Pérez-Iñigo \& Baggio is species description, but they do not include detailed lists of species.

From the oribatid species from Paraguay, cited by Mahunka (1984), 55\% are presumptively endemic; the same is reported for those species collected by Pérez-Iñigo \& Baggio (1980) from many sites of São Paulo state. In our study, we collected nine species $(9.4 \%)$, probably new to science, whereas $30(31.2 \%)$ need revision for a final identification. The remaining 57 species (approximately $60 \%$ ) are known from other areas.

\section{Conclusions}

1. The high number of taxa found in this study indicates great diversity of oribatid mites in tropical areas, and the great number of new citations for Argentina reveals the pertinence of this kind of work for such areas.

2. The phylogenetic pattern of association among oribatid taxa and vegetation type can be an indication of habitat dependence of this group. 


\section{Acknowledgements}

To biologists Vanesa Lucero and Matías Maggi, for collecting soil samples in the mixed forests out of Iguazú National Park.

\section{References}

BALOGH, J.; BALOGH, P. Oribatid mites of the Neotropical region. Budapest: Akadémiai Kiadó, 1988. v.1, 335p.

BALOGH, J.; BALOGH, P. Oribatid mites of the Neotropical region. Amsterdam: Elsevier, 1990. v.2, 333p.

BALOGH, J.; BALOGH, P. The oribatid mites genera of the world. Budapest: The Hungarian National Museum Press, 1992a. v.1, 263p.

BALOGH, J.; BALOGH, P. The oribatid mites genera of the world. Budapest: The Hungarian National Museum Press, 1992b. v.2, 375p.

CAMPANELLO, P.I.; GARIBALDI, J.F.; GATTI, M.G.; GOLDSTEIN, G. Lianas in a subtropical Atlantic Forest: host preference and tree growth. Forest Ecology and Management, v.242, p.250-259, 2007.

CAMPANELLO, P.I.; MONTTI, L.; GOLDSTEIN, G.; MAC DONAGH, P. Reduced impact logging and post-harvesting forest management in the Atlantic Forest: alternative approaches to enhance canopy tree growth and regeneration and to reduce the impact of invasive species. In: GROSSBERG, S.P. (Ed.). Forest management. New York: Nova Science Publishers, 2009. 21p.

DI BITETTI, M.S.; PLACCI, G.; DIETZ, L.A. A biodiversity vision for the Upper Parana Atlantic Forest Ecoregion: designing a biodiversity conservation landscape and setting priorities for conservation action. Washington D.C.: WorldWildlife Fund, 2003. 104p.

GALINDO-LEAL, C.; GUSMÃO CÂMARA, I. Atlantic Forest hotspot status: an overview. In: GALINDO-LEAL, C.; GUSMÃO CÂMARA, I. (Ed.). The Atlantic Forest of South America: biodiversity status, threats and outlook. Washington: Island Press, 2003. p.3-11.

GATTI, M.G. Ecofisiología de una palmera arbórea (Euterpe edulis) del Bosque Atlántico: crecimiento, fotosíntesis, arquitectura hidráulica y resistencia a las bajas temperaturas. 2005. 162p. Thesis (Ph.D.) - Universidad de Buenos Aires, Buenos Aires.

HOLZ, S.; PLACCI, G. Socioeconomic roots of biodiversity loss in Misiones. In: GALINDO-LEAL, C.; GUSMÃO CÂMARA, I. (Ed.). The Atlantic Forest of South America: biodiversity status, threats and outlook. Washington: Island Press, 2003. p.141-159.

LIGIER, H.D. Caracterización geomorfológica y edáfica de la Provincia de Misiones. Corrientes: Instituto Nacional de Tecnología Agropecuaria, 2000. 28p. (Technical Report to Fundación Vida Silvestre Argentina).

MAHUNKA, S. Neue und interessante Milben aus dem Genfer Museum. XLVIII. Oribatida Americana 8: Paraguay I (Acari). Revue Suisse de Zoologie, v.91, p.109-147, 1984.

MORENO, C.E. Métodos para medir la biodiversidad. Zaragoza: Sociedad Entomológica Aragonesa, 2001. 83p. (Manuales y tesis).
MYERS, N.; MITTERMEIER, R.A.; MITTERMEIER, C.G.; FONSECA, G.A.B.; KENT, J. Biodiversity hotspots for conservation priorities. Nature, v.403, p.853-845, 2000.

OLIVEIRA, A.R.; NORTON, R.A.; DE MORAES, G.J. Edaphic and plant inhabiting oribatid mites (Acari: Oribatida) from Cerrado and Mata Atlantica ecosystems in the State of Sao Paulo, southeast Brazil. Zootaxa, v.1049, p.49-68, 2005.

OLIVEIRA-FILHO, A.T.; FONTES, M.A.L. Patterns of floristic differentiation among Atlantic Forests in southeastern Brazil and the influence of climate. Biotropica, v.32, p.793-810, 2000.

PÉREZ-IÑIGO, C.; BAGGIO, D. Oribates édaphiques du Brésil (II). Oribates de 1'Île du "Cardoso" (Première partie). Acarologia, v.26, p.183-189, 1985.

PÉREZ-IÑIGO, C.; BAGGIO, D. Oribates édaphiques du Brésil (III). Oribates de l'Île du "Cardoso" (Deuxième partie). Acarologia, v.28, p.164-179, 1986.

PÉREZ-IÑIGO, C.; BAGGIO, D. Oribates édaphiques du Brésil (IV). Oribates de l'État de Sao Paulo (Première partie). Acarologia, V.29, p.189-204, 1988.

PÉREZ-IÑIGO, C.; BAGGIO, D. Oribates édaphiques du Brésil (V). Oribates de l'État de Sao Paulo (Deuxième partie). Acarologia, v.30, p.261-274, 1989.

PÉREZ-IÑIGO, C.; BAGGIO, D. Oribates édaphiques du Brésil (VI). Oribates de 1'État de Sao Paulo (Troisième partie). Acarologia, v.32, p.79-92, 1991.

PÉREZ-IÑIGO, C.; BAGGIO, D. Oribates édaphiques du Brésil (VII). Oribates de 1'État de Sao Paulo (Quatrième partie). Acarologia, v.34, p.249-264, 1993.

PÉREZ-IÑIGO, C.; BAGGIO, D. Oribates édaphiques du Brésil (VIII). Oribates de 1'État de Sao Paulo (Cinquième partie). Acarología, v.35, p.181-198, 1994.

PÉREZ-IÑIGO, C.; BAGGIO, D. Oribátidos edáficos do Brasil. I. Boletim de Zoologia da Universidade de São Paulo, v.5, p.111-147, 1980.

SRUR, M.; GATTI, F.; BENESOVSKY, V.; HERRERA, J.; MELZEW, R.; CAMPOSANO, M. Identificación, caracterización y mapeo de los ambientes del Parque Nacional Iguazú. Puerto Iguazú: Centro de Investigaciones Ecológicas Subtropicales, 2007. 118p. (Technical Report to Administración de Parques Nacionales).

SUBÍAS, L.S. Listado sistemático, sinonímico y biogeográfico de los Ácaros Oribátidos (Acarifomes, Oribatida) del mundo (1748-2002). Graellsia, v.60, p.3-305, 2004.

TABARELLI, M.; PINTO, L.P.; SILVA, J.M.C.; HIROTA, M.M.; BEDÊ, L.C. Desafios e oportunidades para a conservação da biodiversidade na Mata Atlântica brasileira. Megadiversidade, v.1, p.132-138, 2005.

TUJCHNEIDER, O.; PÉREZ, M.; PARIS, M.; D'ELIA, M. The Guaraní aquifer system: state-of-the-art in Argentina. In: In: CHERY, L.; MARSILY, G. de (Ed.). Aquifers system management: Darcy'S legacy in a world of impeding water shortage. Leiden: Taylor and Francis/Balkema, 2007. p.239-252.

Received on September 29, 2008 and accepted on July 21, 2009 